\title{
PERANCANGAN MULA KLINIK APUNG UNTUK PELAYANAN KESEHATAN MASYARAKAT LINTAS HINTERLAND BATAM
}

\author{
Naufal A Prasetyo ${ }^{1)}$, Sapto Wiratno Satoto ${ }^{2)}$ \\ 1) Prodi Teknik Perencanaan dan Konstruksi Kapal, Politeknik Negeri Batam \\ 2) Prodi Teknik Mesin, Politeknik Negeri Batam \\ Email:abdurrahman@polibatam.ac.id
}

\begin{abstract}
Abstrak
Klinik apung berfungsi sebagai sarana pendukung pelayanan masyarakat dikawasan hinterland Batam. Penelitian ini bertujuan menilai fisibilitas secara teknis pada tahap perancangan mula berkaitan dengan kebutuhan daya mesin penggerak dan penilaian ketegaran fisik ketika mengalami gaya luar sesuai dengan batasan kriteria gelombang dan karakteristik perairan di wilayah operasional klinik apung. Metode pembahasan mengacu pada desain konseptual klinik apung yang berdasar kebutuhan pengguna. Klinik apung yang direncanakan memiliki dimensi length over all : 10,00 m; Breadth : 3,5 m; Depth : 1,7 m; Draught : 0,5 m serta memiliki karakteristik fisik luasan basah badan yang tercelup dalam air sebesar $21 \mathrm{~m}^{2}$, luasan permukaan bidang air $18,71 \mathrm{~m}^{2}$. Daya efektif untuk mengoperasikan klinik apung dengan kecepatan operasional 28 knot diestimasikan sebesar $523 \mathrm{HP}$. Aspek ketegaran fisik dalam menerima gaya luar dianalisa menggunakan 2 (dua) variasi kecepatan 0 knot dan 12,5 knot dengan lima variasi input sudut heading 0 deg, 45 deg, 90 deg, 135 deg dan 180 deg. Kondisi heave terbesar pada sudut heading $135 \mathrm{deg}$. Kondisi pitch terbesar dengan sudut heading 180 deg dan kondisi roll pada sudut heading $135 \mathrm{deg}$.
\end{abstract}

KataKunci: fisibilas, klinik apung, batam

\begin{abstract}
Floating clinic's function is to support the health services to citizen in around Batam's hinterland. This research has aim to evaluate technical feasibility at early stage of design process, due to requirements of engine mover and seakeeping. Floating Clinic serves as a means of supporting public services in Batam hinterland. The objective of this research is to evaluate the technical feasibility related to requirement of engine power and assessment of physical fitness when experiencing outer force in accordance with boundary of wave criteria and characteristics of waters in operational area of floating clinic. The method of discussion refers to the conceptual design of floating clinics based on user needs. The floating cluster is planned to have a dimension of length over all: $10.00 \mathrm{~m}$; Breadth: $3.5 \mathrm{~m}$; Depth: $1.7 \mathrm{~m}$; Draft: $0.5 \mathrm{~m}$ as well as having physical characteristics of wetted surface area of $21 \mathrm{~m}^{2}$, surface area of water $18,71 \mathrm{~m}^{2}$. Effective power to operate floating clinics with a $28 \mathrm{knot}$ operational speed is estimated at $523 \mathrm{HP}$. Physical fitness aspects in accepting outside forces were analyzed using 2 (two) variations of 0 knot and 12.5 knot velocity with five angle input variations of 0 deg, $45 \mathrm{deg}$, 90 deg, $135 \mathrm{deg}$ and $180 \mathrm{deg}$. The largest heave condition at $135 \mathrm{deg}$. The largest pitch condition with 180 degrees heading angle and roll condition at 135 deg heading angle.
\end{abstract}

Keywords: fisibility, floating clinic, batam

\section{Pendahuluan}

Armada terapung yang dapat bergerak (kapal) menjadi sebuah kebutuhan mendasar untuk perpindahan orang dan barang diatas permukaan air. Kota Batam sebagai bagian kecil dari daerah adminitrasi Provinsi Kepulauan Riau yang cakupan wilayah banyak terdapat pulau yang dipisahkan oleh perairan membutuhkan banyak armada kapal sebagai sarana transportasi masyarakat lintas pulau. Pada kondisi normal, kapal merupakan sarana yang amat vital apalagi dalam kondisi darurat, seperti misalnya untuk menghantarkan orang sakit.

Masyarakat yang tinggal di daerah kepulauan dengan waktu tempuh yang relatif lama dari pulau utama sangat membutuhkan sarana transportasi untuk membawa orang sakit ke tempat pengobatan rujukan. Seperti contoh kasus apabila ada orang yang hendak melahirkan darurat atau kondisi tertentu yang mengharuskan pasien dirujuk ke rumah sakit dengan fasilitas yang lebih baik. Hal ini bisa dikaitkan dengan 
terbatasnya fasilitas kesehatan di pulau dimana mereka tinggal.

Berlayar ke pulau utama dan berobat ke rumah sakit daerah/ swasta di pulau utama merupakan salah satu usaha mengantisipasi kondisi darurat yang diderita pasien. Namun serangkaian perjalanan dari pulau ke Rumah Sakit bukan hal yang mudah, karena harus melalui moda transportasi darat - laut - darat yang membutuhkan biaya tidak sedikit. Apalagi jika pasien maupun keluarga dari keluarga dengan pendapatan yang kurang memenuhi [1].

Sebaran pulau mainland-hinterland daerah industri batam sangat luas dengan jarak yang bervariasi antar pulau (lihat Gambar 1). Selama ini, transportasi untuk mengantar pasien mengandalkan kapal yang digunakan sehari-hari untuk bekerja mencari ikan, mengangkut orang maupun barang antar. Kapal tersebut tidak memiliki fasilitas kesehatan dasar seperti obat-obatan, tabung oksigen, tempat tidur pasien. Keadaan cuaca juga sangat mempengaruhi akses transportasi. Apabila gelombang tinggi, maka warga tidak berani berlayar karena resiko kapal terhantam gelombang. Dari beberapa kasus yang terjadi dan hasil koordinasi dengan beberapa sumber, maka perlu ada upaya untuk mengukur kelayakan secara teknis armada klinik apung sebagai sarana pelayanan kesehatan. Mengingat dalam kondisi sakit, kondisi pasien membutuhkan perlakuan khusus.



Gambar 1. Peta Kepulauan Batam

Unjuk kerja kapal secara dinamis bergantung pada perilaku dan respon badan kapal terhadap kondisi perairan dimana kapal dioperasikan. Pada saat beoperasi, kapal akan mengalami gerakan yang disebabkan kapal itu sendiri (maneuverability) maupun dari faktor luar (seakeeping). Faktor luar misalnya berupa cuaca buruk yang mengakibatkan terjadinya gelombang besar yang membahayakan keselamatan kapal apabila kapal tidak mampu merespon gelombang tersebut. Untuk itulah kapal harus memiliki performa seakeeping yang memenuhi batasan kriteria [2].

Armada klinik terapung beroperasi di perairan lintas hinterland Batam dengan karakter gelombang dinamis memerlukan penilaian olah gerak kapal sehingga bisa menjadi alat transportasi perairan yang handal. Mengingat klinik apung selain mengangkut awak kapal, juga digunakan untuk mengangkut orang sakit sehingga kenyaman seyogyanya lebih diperhatikan. Penilaian seakeeping menggunakan pendekatan statistik yang mengacu pada batasan kriteria menurutkondisi laut dan skenario navigasi pelayaran. Penilaian kinerja seekeeping didasarkan pada osilasi respon dinamis kapal pada gelombang tak beraturan, sesuai dengan kondisi perairan [3].

Relasi antara kemampuan kapal beroperasi dengan karakteristik gerakan kapal diperlihatkan dalam kriteria seakeeping yang merepresentasikan batasan kondisi operasi kapal yang dapat diterima oleh kapal. Penilaian performa seakeeping pada perairan Laut Hitam menunjukkan bahwa sudut wave heading pada haluan mempengaruhi kecepatan kapal karena performa merupakan fungsi karakteristik hidrodinamis dan kondisi perairan dimana kapal beoperasi [4].

Dari latar belakang kondisi geografis di daerah Batam serta kebutuhan pelayanan kesehatan untuk masyarakat di kawasan hinterland, maka perlu adanya fasilitas pelayanan klinik terapung. Tujuan penelitian adalah menilai fisibilitas secara teknis pada tahap perancangan mula berkaitan dengan kebutuhan daya mesin penggerak dan penilaian ketegaran fisik ketika mengalami gaya luar sesuai dengan batasan kriteria gelombang dan karakteristik perairan di wilayah operasional klinik apung.

\section{Landasan Teori}

\subsection{Kondisi Geografis Hinterland Batam}

Wilayah kota Batam seperti halnya kecamatan di daerah administratif lain di Kepulauan Riau, termasuk bagian dari paparan kontinental. Pulaupulau yang tersebar didaerah ini merupakan sisasisa erosi atau penyusutan dari daratan pra tersier yang membentang dari semenanjung Malaysia/ pulau Singapura di bagian utara sampai dengan pulau-pulau Moro dan Kundur serta karimun di bagian selatan. Permukaan tanah di kota batam pada umumnya dapat digolongkan datar dengan variasi kontur daratan dengan ketinggian maksimum $160 \mathrm{~m}$ diatas permukaan laut. Sungaisungai kecil banyak mengalir dengan aliran sedang dan dikelilingi hutan-hutan serta semak belukar. Pulau-pulau tersebar dihubungkan dengan perairan dengan kedalaman bervariasi. Ketinggian gelombang perairan di kawasan hinterland diperkirakan 0,3 sampai 1,3 meter [5].

\subsection{Klinik Apung}

Klinik apung secara fisik sama dengan kapal dalam kaidah secara umum. Yang membedakan adalah fasilitas yang dimiliki dimana klinik merupakan representasi klinik di darat yang diimplementasikan dalam bentuk kapal. Desain awal klinik apung untuk penggunaan di perairan Batam ditampilkan pada Gambar 2 sebagai gambaran awal klinik apung. 
Kaidah perancangan kapal adalah menggunakan konsep spiral design dengan pengertian sederhana serangkaian proses perancangan tidak berlangsung searah. Hal ini terjadi karena konstruksi kapal dan sistem dalam kapal merupakan sebuah sistem yang saling berkaitan dan kompleks. Sehingga perubahan pada satu parameter, akan mempengaruhi parameter yang lain. Parameter awal perancangan kapal adalah owner requirement, dimana kapal yang dibangun harus mengakomodir kebutuhan pengguna. Beberapa contoh yang berkaitan dengan owner requirements seperti kapasitas muatan, kecepatan kapal, batasan dimensi kapal, batasan alur perairan, kebutuhan pengawakan kapal, akses bongkar muat, jenis mesin yang terpasang, jenis bahan bakar yang tersedia dan batasan biaya investasi yang tersedia untuk membangun kapal.

Berkaitan dengan fungsinya sebagai sarana kesehatan, maka kondisi strukturkapal dan pergerakan kapal dapat mengakomodir untuk kondisi tindakan dan penanganan medis.

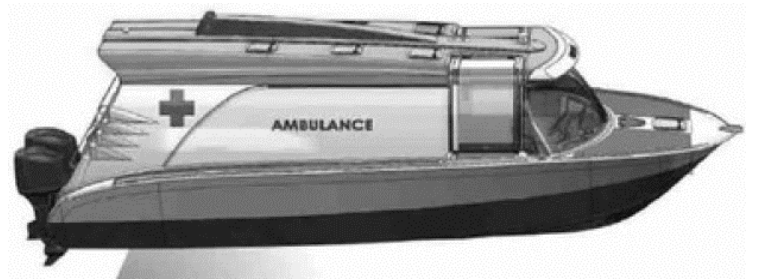

Gambar 1. Sketsa Awal Klinik Apung

Gambar 2 menampilkan sketsa awal bentuk fisik klinik apung sebagai visualisasi dan gambaran untuk proses teknis lanjutan dari tahapan perancangan kapal. Interior dalam kapal mengikuti kebutuhan peralatan dan tenaga medis untuk melakukan tindakan medis dan pengkondisian pasien yang dibawa. Akses keluar masuk juga harus memungkinkan untuk memudahkan pemindahan pasien dari daratan ke klinik apung dan sebaliknya.

\subsection{Seakeeping}

Gambar 3 mengilustrasikan gerakan dinamis kapal pada fluida air dapat dikategorikan secara 6 derajat kebebasan yang terbagi dalam 2 (dua) jenis gerakan [6], pertama, gerakan rotasi (putaran) : roll (sumbu $x$ ), yaw (sumbu y), pitch (sumbu z); kedua, gerakan translasi (linear) : surge (sumbu $x$ ), sway (sumbu $y$ ), heave (sumbu $z$ ).

Seakeeping adalah respon gerakan kapal yang dipengaruhi oleh gaya-gaya luar yang disebabkan oleh kondisi air laut. Dalam kajian seakeeping, gerakan yang ditinjau merupakan gerakan yang hanya mampu direspon oleh kapal, yaitu heave, pitch, roll: (1) heave - gerakan kapal yang sejajar sumbu $z$ dan saat terjadi heave kapal mengalami naik turun secara vertikal; (2) pitch- gerakan kapal yang memutari sumbu $y$, ketika terjadi pitch kapal mengalami perubahan trim bagian bow dan stern secara bergantian; (3) roll - gerakan kapal yang mengelilingi sumbu $x$, ketika terjadi rolling bagian sisi kanan kapal bergerak ke sebelah bagian sisi kiri kapal yang terulang secara bergantian [2].



Gambar 2. Gerakan kapal dengan enam derajat kebebasan [9]

Respon gerakan kapal terhadap gelombang reguler dinyatakan dalam Response Amplitude Operator (RAO), dimana RAO adalah rasio antara amplitudo gerakan kapal (baik translasi maupun rotasi) terhadap amplitudo gelombang pada frekuensi tertentu. Metode untuk menghitung nilai RAO pada penelitian ini menggunakan Strip Theory. RAO untuk gerakan translasi merupakan perbandingan langsung antara amplitudo gerakan kapal dengan amplitudo gelombang yang keduanya dalam satuan panjang. Sedangkan gerakan rotasi merupakan perbandingan antara amplitudo gerakan rotasi (dalam radian) terhadap kemiringangelombang yang merupakan perkalian angka gelombang, $\mathrm{kw}=\omega 2 / \mathrm{g}$ dengan amplitudo gelombang [7].

Pada kenyataannya, gelombang di laut adalah gelombang acak sehingga respon kapal terhadap gelombang reguler yangdinyatakan dalam RAO tidak dapat menggambarkan respon kapal pada keadaan sesungguhnya di laut. Untuk mendapatkan respon gerakan kapal terhadap gelombang acak dapat digambarkan dengan spektrum respon. Spektrum respon didapatkan dengan mengalikan spektrum gelombang. Adapun spektrum gelombang yang digunakan dalam penelitian ini adalah Bretschneider atau ITTC dengan 2 parameter. Tinggi gelombang signifikan $\left(\mathrm{H}_{\mathrm{s}}\right)$ yang digunakan adalah $1,00 \mathrm{~m}$ dengan Periode Rata-rata ( $\left.\mathrm{T}_{\mathrm{av}}\right)$ 5,00 detik.

\section{Hasil dan pembahasan}

Alur penelitian dijabarkan dengan tahapan yang tercantuk pada point 3, yang meliputi parameter desain dasar, karakteristik hidrostatis, mengestimasi kebutuhan daya mesin penggerak dan terakhir menilai ketegaran fisik klinik apung ketika menerima gaya luar. 


\subsection{Parameter Desain Konseptual}

Tujuan utama dari perancangan selain untuk membuat informasi-informasi yang dibutuhkan dalam membangun kapal adalah untuk memenuhi kebutuhan pengguna (user requirement) dalam hal penggunaan dan operasional dengan biaya seminimal mungkin sehingga didapatkan nilai investasi yang ekonomis. Kaidah ekonomis dalam artian biaya perencanaan serta pembangunan kapal sejak awal hingga operasi sesuai dengan benefit dan keuntungan yang didapatkan oleh pengguna. Dasar pertimbangan awal berdasar kebutuhan pengguna meliputi fungsi, pola operasional dan spesifikasi umum klinik apung disajikan pada Tabel 1.

Serangkaian proses perancangan kapal memiliki kaidah desain spiral, dalam artian proses desain tidak kaku dan searah. Ketika pada tahapan tertentu desain tidak sesuai dengan kebutuhan pengguna maupun standar yang diinginkan, maka proses berulang ke awal untuk penyesuaian. Perubahan satu parameter pada proses desain akan berpengaruh pada parameter lain.

TABEL 1

KEBUTUHAN PENGGUNA KLINIK APUNG

\begin{tabular}{|c|c|c|}
\hline No & Item & Keterangan \\
\hline 1 & $\begin{array}{l}\text { Fungsi kapal } \\
\text { Ambulance }\end{array}$ & $\begin{array}{ll}\text { 1. } & \text { Mobilisasi (mengantar } \\
\text { pasien dari pulau ke } \\
\text { Rumah Sakit di Mainland } \\
\text { Batam) } \\
\text { 2. } \begin{array}{l}\text { Kegiatan sosial (sunat, cek } \\
\text { mata, cek kesehatan }\end{array} \\
\text { umum, 3T, dll) } \\
\text { 3. } \\
\text { 43K } \\
\text { 4. Fungsi SAR }\end{array}$ \\
\hline 2 & Target pulau & $\begin{array}{l}\text { 1. Pulau kubung, Pulau selat } \\
\text { Desa, Kec. Nongsa } \\
\text { 2. Kawasan hinterland Batam }\end{array}$ \\
\hline 3 & $\begin{array}{l}\text { Spesifikasi } \\
\text { umum kapal }\end{array}$ & $\begin{array}{ll}\text { 1. } & \text { Operasional: } \\
\text { terjadwal/insidensial } \\
\text { 2. } & \text { Spesifikasi } \\
\text { - } & \text { Jumlah tenaga medis: } 2 \\
& \text { org } \\
\text { - } & \text { Jumlah pasien yang bisa } \\
& \text { ditampung: } 2 \text { orang } \\
\text { - } & \text { Standar mobil ambulance } \\
\text { - } & \text { Kebutuhan } \\
& \text { kecepatan/mesin: bisa } \\
& \text { digunakan untuk } \\
& \text { emergency } \\
\text { - } & \text { Peralatan medis: bed, } \\
\text { lemari, oksigen (standar } \\
\text { mobil ambulance) }\end{array}$ \\
\hline
\end{tabular}

Perencanaan kapal merupakan salah satu tugas dari desainer untuk membuat pengguna kapal memahami dan menyadari pemilihan desain yang efisien dalam hal biaya operasional kapal dan perawatannya. Adapun tujuan desain yang utama adalah untuk membuat armada yang aman, handal dalam pengoperasian dan perawatan dalam batasan yang diperkenankan oleh teknologi dan anggaran pemilik / pengguna kapal. Ketika desain sudah disepakati bersama, selanjutnya diserahkan ke builder kapal untuk implementasi pembangunan fisik kapal dalam bentuk nyata.

Koreksi dalam hal perancangan adalah suatu hal yang wajar, mengingat perubahan parameter akan mempengaruhi parameter yang lain sehingga berlaku desain spiral, dalam artian proses perancangan berlangsung spiral sehingga hasil pada sebuah proses disepakati oleh pihak-pihak yang berkepentingan.

Dengan mempertimbangkan kebutuhan dari pengguna, peneliti melakukan perbandingan dengan ukuran mobil ambulance standar tipe all purpose vehicel (APV) yang memiliki panjang 4,3 m, lebar $1,69 \mathrm{~m}$, tinggi $1,86 \mathrm{~m}$ [8]. Dimensi yang terbatas hanya memuat 1 pasien kurang efisien untuk keperluan tindakan sosial, misalnya imunisasi, cek kesehatan, dan lain sebagainya. Sehingga peneliti mempertimbangkan dimensi kapal kecil yang bisa mengakomodir kebutuhan pengguna. Basis data rujukan terdapat beberapa opsi ukuran dari 5 meter sampai 24 meter untuk jenis kapal kecil [9]. Hasil desain konseptual dan sketsa awal (lihat Gambar 4) dengan memperkirakan kebutuhan pengguna mendapatkan dimensi utama kapal secara keseluruhan, yaitu:

Length over all (loa) : 10,00 m

$\begin{array}{ll}\text { Breadth } & : 3,5 \mathrm{~m} \\ \text { Depth } & : 1,7 \mathrm{~m} \\ \text { Draught } & : 0,5 \mathrm{~m}\end{array}$

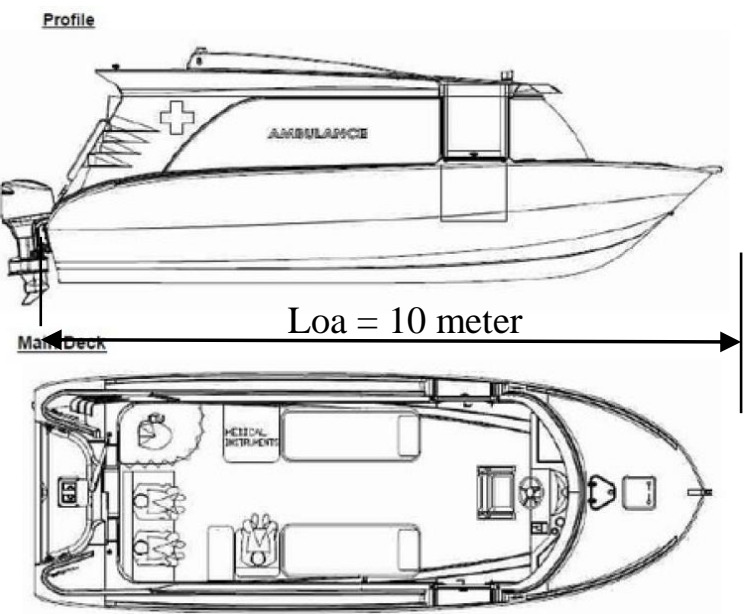

Gambar 4. Rencana Umum Klinik Apung

\subsection{Karakteristik hidrostatis}

Tiap kapal yang berbeda akan memiliki karateristik lambung kapal yang berbeda. Dengan menggunakan bantuan perangkat lunak untuk desain kapal, klinik apung memiliki karakteristik lambung dibawah garis air yang disajikan pada Tabel 2 dimana nilai displacement diperkirakan 5,3 ton dengan luasan basah badan kapal $21 \mathrm{~m}^{2}$. 
TABEL 2

HIDROSATIS KLINIK APUNG

\begin{tabular}{|c|c|c|c|}
\hline $\begin{array}{c}\text { Draft Amidships } \\
\text { M }\end{array}$ & 0.000 & 0.352 & 0.501 \\
\hline Displacement $\mathrm{t}$ & 0.0000 & 2.650 & 5.300 \\
\hline Heel deg & 0.0 & 0.0 & 0.0 \\
\hline Draft at FP m & 0.000 & 0.352 & 0.501 \\
\hline Draft at AP m & 0.000 & 0.352 & 0.501 \\
\hline Draft at LCF $m$ & 0.000 & 0.352 & 0.501 \\
\hline WL Length $\mathrm{m}$ & 5.083 & 8.366 & 8.610 \\
\hline $\begin{array}{l}\text { Beam max extents } \\
\text { on WL m }\end{array}$ & 0.026 & 2.333 & 2.730 \\
\hline Wetted Area $\mathrm{m}^{\wedge} 2$ & 0.047 & 15.882 & 21.003 \\
\hline Waterpl. Area $\mathrm{m}^{\wedge} 2$ & 0.047 & 14.769 & 18.713 \\
\hline $\begin{array}{l}\text { Prismatic coeff. } \\
(\mathrm{Cp})\end{array}$ & 0.360 & 0.781 & 0.759 \\
\hline Block coeff. $(\mathrm{Cb})$ & 0.360 & 0.377 & 0.439 \\
\hline $\begin{array}{l}\text { Max Sect. area } \\
\text { coeff. }(\mathrm{Cm})\end{array}$ & 1.000 & 0.482 & 0.579 \\
\hline $\begin{array}{l}\text { Waterpl. area } \\
\text { coeff. (Cwp) }\end{array}$ & 0.360 & 0.757 & 0.796 \\
\hline $\begin{array}{l}\text { LCB from zero pt. } \\
(+\mathrm{ve} \text { fwd }) \mathrm{m}\end{array}$ & 1.524 & 3.585 & 3.567 \\
\hline $\begin{array}{l}\text { LCF from zero pt. } \\
\text { (+ve fwd) m }\end{array}$ & 1.527 & 3.527 & 3.641 \\
\hline $\mathrm{KB} \mathrm{m}$ & 0.000 & 0.234 & 0.331 \\
\hline KG m & $\overline{0.500}$ & 0.500 & 0.500 \\
\hline BMt m & 7.219 & 1.933 & 1.823 \\
\hline BML $\mathrm{m}$ & 257889.225 & 25.800 & 17.167 \\
\hline GMt $\mathrm{m}$ & 6.719 & 1.667 & 1.654 \\
\hline GML m & 257888.725 & 25.534 & 16.999 \\
\hline KMt m & 7.219 & 2.167 & 2.154 \\
\hline KML m & 257889.225 & 26.034 & 17.499 \\
\hline $\begin{array}{l}\text { Immersion (TPc) } \\
\text { tonne/cm }\end{array}$ & 0.000 & 0.151 & 0.192 \\
\hline MTc tonne.m & 0.000 & 0.079 & 0.105 \\
\hline $\begin{array}{l}\text { RM at 1deg = } \\
\text { GMt.Disp.sin(1) } \\
\text { tonne.m }\end{array}$ & 0.000 & 0.077 & 0.153 \\
\hline
\end{tabular}

\subsection{Kebutuhan Effective Horse Power}

Daya efektif merupakan nilai nilai yang diperlukan untuk menggerakan bangunan apung di air tanpa adanya sistem propulsi mandiri. Hasil analisa EHP dengan program komputer ditampikan pada Tabel 3 bahwa untuk kecepatan kisaran 28 knot, klinik apung memiliki nilai tahanan total sebesar $19 \mathrm{kN}$ sehingga estimasi kebutuhan daya efektif berkisar 523.341 HP. Dengan nilai daya efektif tersebut, mesin penggerak kapal yang direncanakan akan dipasang pada klinik apung berupa mesin outboard. Opsi instalasi menggunakan 2 unit mesin @250HP, dengan pertimbangan ketika beroperasi pada kecepatan rendah dapat menggunakan 1 mesin.
TABEL 3

HASIL EHP

\begin{tabular}{|r|r|r|}
\hline $\begin{array}{l}\text { Speed } \\
(\mathbf{k n})\end{array}$ & $\begin{array}{l}\text { Rt } \\
(\mathbf{k N})\end{array}$ & $\begin{array}{l}\text { EHP } \\
\text { (HP) }\end{array}$ \\
\hline 0 & -- & -- \\
\hline 0.875 & 0 & 0.013 \\
\hline 7 & 1.4 & 9.499 \\
\hline 14 & 9.1 & 125.72 \\
\hline 21 & 13 & 269.997 \\
\hline 28 & 19 & 523.341 \\
\hline 35 & 25.8 & 890.39 \\
\hline
\end{tabular}

\subsection{Ketegaran Terhadap Beban Eksternal}

Karakteristik perairan menggunakan metode Pierson Moskowitz spectrum data yang dimasukkan adalah kecepatan angin sebesar 10,17 m/s knot, Char. Height $0,534 \mathrm{~m}$, modal period $3,652 \mathrm{~m}$, average period 2,822 $\mathrm{s}$ [10]. Input karakteristik seaway perairan Batam menggunakan metode Pierson - Moskowitz, dimana distribusi spektrum gelombang digambarkan secara keseluruhan dan ditentukan oleh satu parameter kecepatan angin. Pencapaian dan durasi dianggap infinite. Untuk aplikasi model, angin berhembus pada area luas dengan kecepatan konstan dengan waktu yang lama. Berdasar asumsi tersebut, model P-M dapat digunakanuntuk mepresentasikan beberapa gelombang pada perancangan struktrur lepas pantai. Hasil penilaian performa seakeeping kapal bisa dilihat berupa sajian grafik di Gambar 5-7.

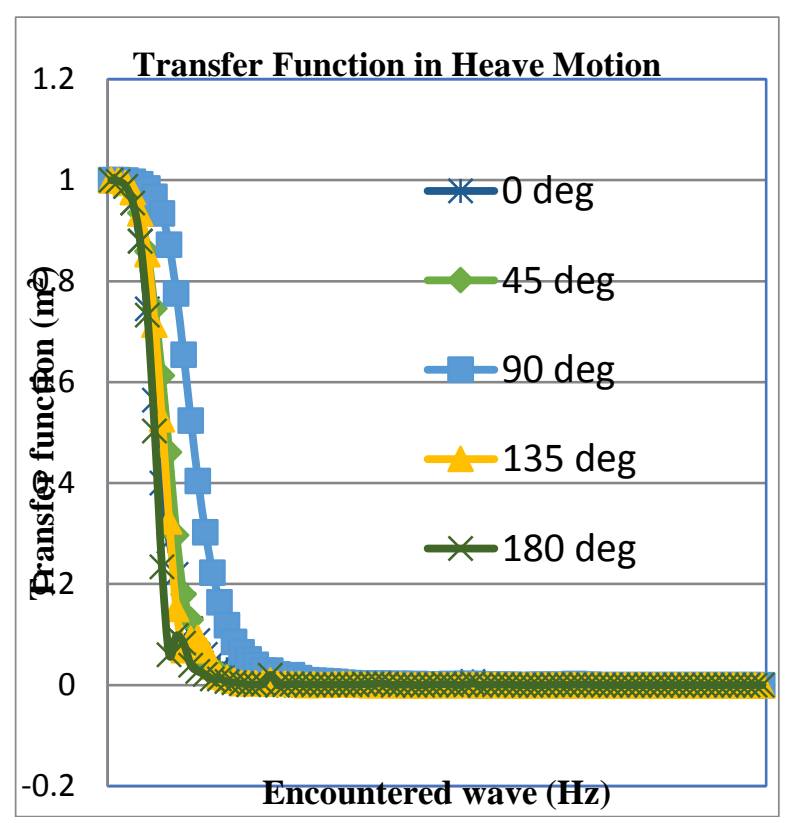

Gambar 5. Transfer Function pada Gerakan Heave

Gambar 5 menunjukkan RAO (Response Amplitudo Operator) atau transfer function pada gerakan heave untuk sudut heading 0, 45 dan $90 \mathrm{deg}$. Formula (1) merupakan dasar untuk menghitung periode heaving (TH). 
$\mathrm{TH}=2(\mathrm{~d} * \mathrm{Cb} / \mathrm{Cw}) 0.5$ (detik)

Dimana $\mathrm{d}=$ sarat kapal; $\mathrm{Cb}=$ koefisien blok; $\mathrm{Cw}=$ koefisien garis air.

Gambar 6 menampilkan tren transfer function pada gerakan pitch untuk semua sudut dengan nilai pitch paling tinggi pada sudut heading $180 \mathrm{deg}$. Sudut 0 deg, 45 deg dan 90 deg relatif kecil.

Selain heaving, yang menjadi perhatian parameter adalah periode pitching dengan formula basis

$$
\frac{T_{p}}{\sqrt{L}}=C \sqrt{\frac{\Delta}{(0.01 L)^{3}} * \frac{L}{g}}
$$

Dimana, $\mathrm{C}=$ konstanta $(0.009-0.01) ; \Delta=$ displacement kapal; $\mathrm{L}=$ panjang kapal; $\mathrm{g}=$ gravitasi bumi.

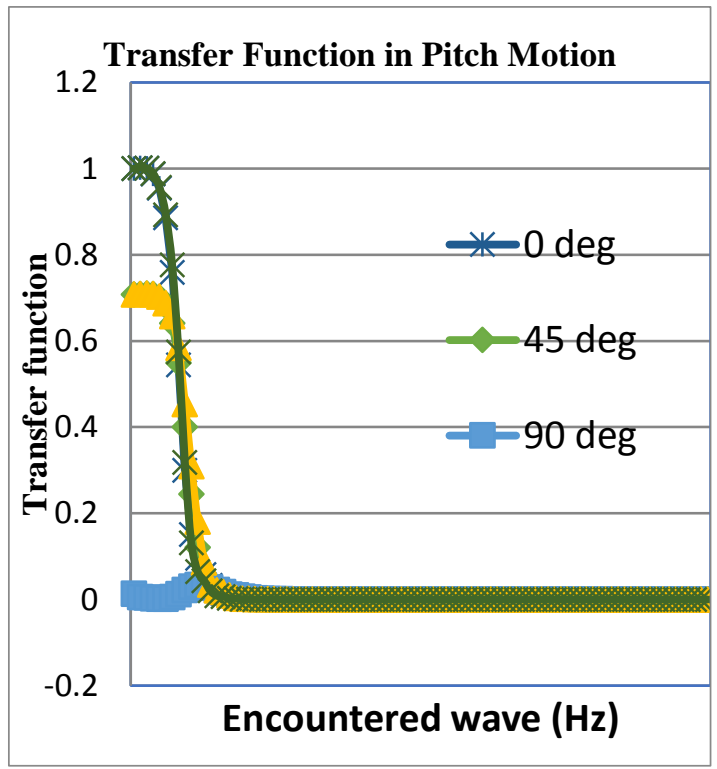

Gambar 6. Transfer Function pada Gerakan Pitch

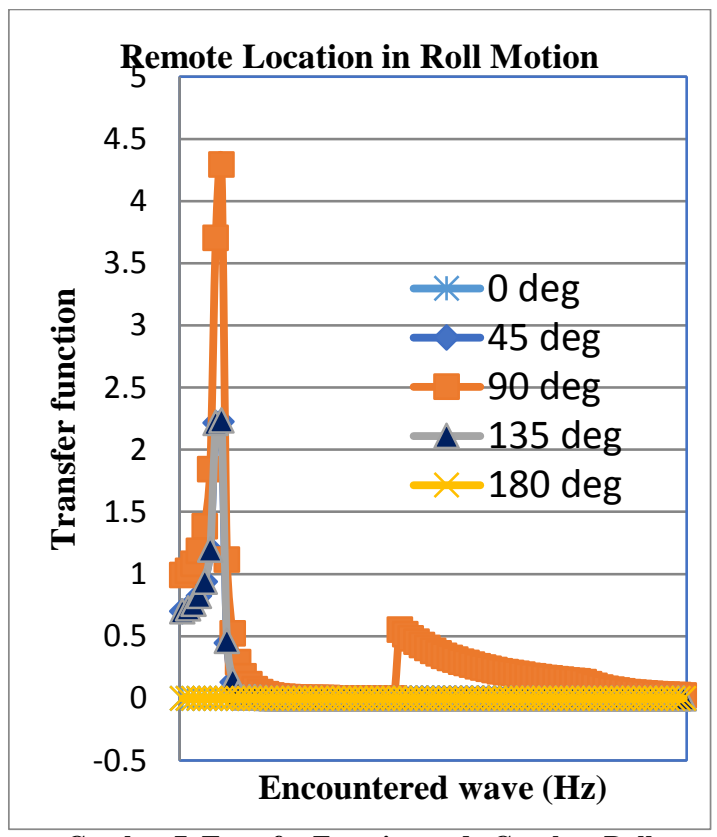

Gambar 7. Transfer Function pada Gerakan Roll
Gambar 7 memperlihatkan gerakan roll dialami kapal secara signifikan pada sudut heading 90 deg dan 135 deg. Periode rolling dihitung dengan persamaan (8).

$$
T_{\varnothing}=2 \pi \sqrt{\frac{I_{x x}}{\Delta G M_{T}}}
$$

Dimana $T_{\varnothing}=$ periode rolling; $\Delta=$ Displacement; $I_{x x}=$ momen inersia; $G M_{T}=$ jarak transversal titik $\mathrm{G}$ dan $\mathrm{M}$. Salah satu tujuan penilaian ketegaran seakeeping adalah untuk mengetahui efek kebasahan dek (deck wetness) yang diakibatkan naiknya gelombang ke atas dek. Hasil bisa dilihat dari simpangan amplitudo sangat kecil sehingga air tidak masuk ke geladak.

\section{Kesimpulan}

Klinik apung yang rencanakan dengan dimensi length over all : 10,00 m; Breadth : 3,5 m; Depth : 1,7 m; Draught : $0,5 \mathrm{~m}$ memiliki karakteristik fisik luasan basah badan yang tercelup dalam air sebesar $21 \mathrm{~m} 2$, luasan permukaan bidang air 18,71 m2. Daya efektif untuk mengoperasikan klinik apung dengan kecepatan 28 knot diestimasikan sebesar 523 HP.

Aspek ketegaran fisik dalam menerima gaya luar dianalisa menggunakan 2 (dua) variasi kecepatan 0 knot dan 12,5 knot dengan lima variasi input sudut heading 0 deg, $45 \mathrm{deg}, 90 \mathrm{deg}, 135 \mathrm{deg}$ dan $180 \mathrm{deg}$. Kondisi heave terbesar pada sudut heading $135 \mathrm{deg}$. Kondisi pitch terbesar dengan sudut heading $180 \mathrm{deg}$ dan kondisi roll pada sudut heading $135 \mathrm{deg}$. Dari kondisi tersebut menjadi perhatian bagi operator kapal untuk waspada dan memperhatikan arah datangnya serta ketinggian gelombang sehingga kapal saat beroperasi tetap nyaman digunakan.

Saran untuk penelitian lanjutan mengenai klinik apung adalah penilaian stabilitas kapal terhadap kondisi pemuatan disesuaikan dengan pola operasional. Hal ini sangat penting sebagai acuan nakhoda dalam mengoperasikan kapal misal pada kondisi muatan penuh, muatan kosong, saat membawa pasien.

\section{Ucapan Terima Kasih}

Tim Peneliti menyampaikan terimakasih dan apresiasi kepada Pusat P2M Polibatam yang telah mendukung kegiatan penelitian melalui skim penelitian internal tahun 2017.

\section{Daftar Referensi}

[1] Kirfan. 2017. Masyarakat Pulau Simeuleu Butuh Ambulans Laut. - www.goaceh.co

[2] Manik, Parlindungan. 2007. Analisa Gerakan Seakeeping Kapal Pada Gelombang Reguler. Jurnal Kapal, Vol. 4, No. 1, Februari 2007 
[3] Kadir S, Ebru Narli. 2005. Effect of criteria on seakeeping performance assessment, Ocean Engineering, 32, pp. 1161-1173.

[4] Gasparotti, Carmen, Liliana Rusu. 2013. Seakeeping Performance Assessment For a Containership in a Specific Sea Area. Mechanical Testing and Diagnosis. ISSN 2247 - 9635, 2013 (III), Volume 1 pp. 38-48

[5] Naim, Jannatun. 2016. BMKG Batam imbau transportasi laut berhati-hati. www.antaranews.com

[6] Nikolau. 2011. Ship Dynamic in Waves. Universität Rostock. Fakultät für Maschinenbau und schiffstechnik

[7] Iqbal, Muhammad and Good Rindo. 2015. Optimasi Bentuk Demihull Kapal Katamaran Untuk Meningkatkan Kualitas Seakeeping. Jurnal Kapal Vol. 12, No. 1, Februari

[8] Suzuki. 2016. APV new luxury. https://www.suzuki.co.id/automobile/apv-newluxury

[9] Shamsuddin, Mohamad Zawahid. 2003. A Conceptual Design of a FRP Fishing Boat for Traditional Fisheries in Malaysia. UNU Fisheries Training Programme

[10] Dewi, Ratna, et al. 2013. Pendugaan Tinggi Gelombang Berdasarkan Kecepatan Angin Pada Zona Alur Pelayaran Diperairan Tanjung Pinang. Universitas Maritim Raja Ali Haji 